\title{
ERRATUM
}

\section{DNA methylation pattern in pig in vivo produced embryos}

\author{
Josef Fulka $\cdot$ Helena Fulka $\cdot$ Tomas Slavik $\cdot$ \\ Konosuke Okada · Josef Fulka Jr
}

Published online: 1 July 2006

(C) Springer-Verlag 2006

\section{Histochem Cell Biol (2006) \\ DOI 10.1007/s00418-006-0153-x}

Due to an unfortunate error, Acknowledgements were incomplete. The correct text should read as follows:

Acknowledgements Contract grant sponsors: MZe 0002701401 (JF Jr, KO), EUROCORES EuroSTELLS GACR STE/05/E004 and AVOZ50390512 (HF), s.504 5313 and GACR 524/03/0927 (JF, TS).

The online version of the original article can be found at http://dx.doi.org/10.1007/s00418-006-0153-x

J. Fulka $\cdot$ T. Slavik

Center for Cell Therapy and Tissue Repair,

IAPG Czech Academy of Sciences, 27721 Libechov,

Czech Republic

H. Fulka · K. Okada · J. Fulka Jr ( $₫)$

Institute of Animal Production, Pratelstvi 815,

POB 1, 10401 Prague 114, Czech Republic

e-mail: fulka@vuzv.cz

H. Fulka

Institute of Experimental Medicine,

Czech Academy of Sciences, Videnska 1083,

14220 Prague 4, Czech Republic 